\title{
Resesarch Sulure \\ Electrochemical redox treatment of denitrification in coastal secondary effluent using Ti/IrO2 anode
}

\section{Yaozong Zhang ( $\nabla$ zyaozong@163.com)}

North China University of Science and Technology

\section{Bo Pang}

Chinese Research Academy of Environmental Sciences

\section{Research Article}

Keywords: Electrochemistry, denificatioin, high chloride ion, Nitrate-N; ammonia-N, low carbon source

Posted Date: May 3rd, 2021

DOl: https://doi.org/10.21203/rs.3.rs-432243/v1

License: (c) (i) This work is licensed under a Creative Commons Attribution 4.0 International License. Read Full License 


\title{
Electrochemical redox treatment of denitrification in coastal secondary effluent using $\mathrm{Ti} / \mathrm{IrO}_{2}$ anode
}

\author{
ZhangYaozong ${ }^{\mathrm{a}, 1}$, Pang Bo ${ }^{\mathrm{b}}$ \\ ${ }^{a}$ College of Civil and Architectural Engineering, North China University of Science and Technology, Tangshan, PR
}

China

${ }^{\mathrm{b}}$ Chinese research academy of environmental sciences, Beijing, PR China

\section{Abstract :}

In northern coastal industrial park, inlet of the wastewater treatment plant (WWTP) had the characteristics of low carbon source and high chloride ion concentration, which resulted in its poor biodegradability. In this case, the experiment explored an electrochemistral method to remove nitrogen. Cathodic potential, $\mathrm{Ti} / \mathrm{IrO}_{2}$ was confirmed as the anode and $-1.6 \mathrm{~V}$ was taken as the potential in order to remove nitrate-N. The findings include: when the initial chloride ion was 2000 and $3000 \mathrm{mg} / \mathrm{L}$, the effect on the removal difference of nitrogen was slight. When the electrolysis time was 60 min, ammonia-N was removed completely, nitrite-N concentration kept 1mg/L approximately. The ammonia-N removal efficiency went up with the increasing cathodic potential, and was completely removed in different water samples, but nitrate-N removal showed an opposite result. The production amount of nitrite- $\mathrm{N}$ was the least at $-1.6 \mathrm{~V}$. As the $\mathrm{pH}$ increased, ammonia- $\mathrm{N}$ and nitrate-N's removal efficiency went up first and then down, the removal effect was the best at $\mathrm{pH}$ being 9 , Nitrite- $\mathrm{N}$ was less influenced by $\mathrm{pH}$. After optimizing the raw water sample, Nitrate-N and TN removal efficiency were significantly increased, but the

\footnotetext{
1 Corresponding author.

E-mail address:zyaozong@163.com (Y. Zhang)
} 
nitrite-N almost kept constant.

Keywords: Electrochemistry; denificatioin; high chloride ion; Nitrate-N; ammonia-N; low carbon source

\section{Introduction}

China has pulled the discharge standard of pollutant from WWTP up to a higher level. The discharge standard upgraded from Level 1B to Level 1A of Discharge standard of pollutants for municipal wastewater treatment (GB18918-2002) (Chinese national standard). Now many WWTPs in north china are required to meet a higher level to quasi-four standard. Therefore, they are facing the promotion of quasi-four standard. To meet the standard, there are a number of technical barriers to be tackled, one of which is how to lower the concentration of total nitrogen (TN) to $15 \mathrm{mg} / \mathrm{L}$. Many WWTPs are facing the fact that they are lack in carbon sources (a indispensable substance), which causes the TN discharge hard to meet the discharge standard. Compared with municipal WWTPs, costal industrial park plants in north China are confronted with such complicated problems as complex influent quality, low concentration of carbon source and high nitrate- $\mathrm{N}$ and ammonia-N concentration. All of this makes it very difficult to meet the new discharge standard.

There is little research on denitrification of influent from coastal industrial park WWTPs. The groundwater level in coastal areas is high, leaking to sewage pipelines, which leads to a high chloride concentration in influent of WWTP, especially in rainy seasons. Its chloride ion concentration can reach up to $10000 \mathrm{mg} / \mathrm{L}$. It becomes a subject for many engineers and scholars to make full use of the existing high chloride-ion concentration instead of carbon source to remove nitrogen. Current research mainly focuses on the configured sample in the lab. However, there is little experiment on the factual wastewater sample with high chlorine and low carbon from coastal industrial parks WWTPs. 
Two methods are often employed to treat this kind of water, biological and electrochemical denitrification. Since the former requires many carbon sources, the latter becomes a better alternative.

The transformation mechanism from ammonia- $\mathrm{N}$ and nitrate- $\mathrm{N}$ to nitrogen gas was not the same as different denitrification technology. Wang took photoelectrochemical technology to remove ammonia-N, and there was about $49.1 \%$ transformate efficiency of ammonia-N to nitrate-N, (Wang, et al., 2014). Ammonia-N was absorbed onto the electrode and then electrolyzed to nitrogen gas. For photocatalytic fuel cell (PFC), ammonia-N tended to be oxidized to nitrate-N instead of nitrogen gas (Yan et al., 2018). In neutral solution, ammonia-N is oxidized by hydroxyl radicals produced by dissolved oxygen in water instead of adsorbed on the electrode, but the reaction process is very slow (Daye et al., 2018). When chloride ion exists in the solution, ammonia-N can be oxidized to nitrogen gas or nitrogen oxides (Kwang-Wook et al., 2005; Kamai et al., 2017; Garcia-Segura et al., 2019). In the study of nitrate-N electrochemical reduction process, the nitrogen-containing substances could be removed well, and the ideal effect can be achieved (Wei et al., 2018). Taking $\mathrm{Co}_{3} \mathrm{O}_{4} / \mathrm{Ti}$ as the electrode, the nitrate-N removal efficiency reached $96 \%$ (Choi et al., 2016). For the electrode $\mathrm{Pd}-\mathrm{Cu} / \gamma \mathrm{Al}_{2} \mathrm{O}_{3}$, the selectivity of nitrate- $\mathrm{N}$ was about $80.37 \%$ (Yao et al., 2021), and many factors could influence the result. Taking zero valent iron as the reductant, the removal of nitrate reached $83.3 \%$. For Pd-coated alumina pellets, the value was only $64 \%$, and nitrite-N reduction efficiency was only $1 \%$ (Beltramea et al., 2020). In addition, many researchers explored much redox experiment. Under the optimal conditions, it had better nitrate-N reduction effect (Kim et al., 2019; Liu et al., 2019).

Some researchers conducted the experiments with the existence of chloride ion in solution, which can accelerate oxidizing ammonia-N (Zhou et al., 2016) and reducing nitrate-N and produce less nitrogenous byproduct (Yao et al., 2019). So during the electrochemical reaction, chloride ion concentration in solution cannot be neglected. The chloride ion not only increased the conductivity of solution, but also participated in electrochemical 
reaction. This could oxidize the intermediate product (Zöllig et al., 2017) and nitrogen-containing substances (Ma et al., 2016; Ben-Asher et al., 2016; Iranildes et al., 2019). For those experiments, many were conducted in lab with configured solution. However, there were few denitrification experiments on complex, high chloride and low carbon source in wastewater of WWTP in industrial park.

The experiment conducted the denification test by electrochemical technology, and made full use of the characteristics of high chloride and low carbon source in tailwater from costal WWTP, and studied the rules of electrochemical denification under different electrode materials, cathode potential, chloride ion concentration and $\mathrm{pH}$ conditions. The findings provided references for application of electrochemical denitrification of high chloride and low carbon source tailwater from costal industrial park WWTP

\section{Materials and methods}

\subsection{Electrodes and Apparatus}

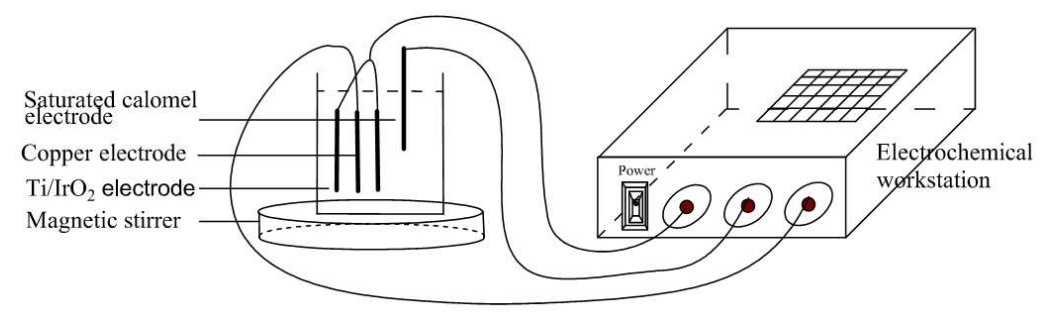

Fig. 1 Experimental apparatus diagram

The experimental apparatus diagram was shown as Fig. 1 and adopted three-dimensional electrode. $\mathrm{Cu}$

(Shenzhen Yunding Metal Material Co., Ltd) was taken as cathode (Jiang et al., 2020), Ti//rO 2 (Baoji Longsheng

Nonferrous Metals Corporation) was the anode, and saturated calomel electrode (Shanghai Leici Electronic

Technology Co., Ltd.) as the referenced anode. The electrode size was $5 \mathrm{~cm} \times 6.5 \mathrm{~cm} \times 0.1 \mathrm{~cm}$, the number ratio of cathode to anode is $2: 1$ and the effective chemical reaction area was $65 \mathrm{~cm}^{2}$ for each. $\mathrm{Cu}$ electrode was set between 
the double $\mathrm{Ti} / \mathrm{IrO}_{2}$ electrodes and the space between the electrodes was $10 \mathrm{~mm}$. The equipment was made by polymethyl methacrylate with the size $5 \mathrm{~cm}, 6 \mathrm{~cm}$ and $12 \mathrm{~cm}$. Electrochemical work station (Tianjin Lanlike chemical and electricity high technology Co., Ltd) was used to adjust the cathode potential.

\subsection{Experimental method and conditions}

In the test, main monitoring items included $\mathrm{TN}$, nitrate- $\mathrm{N}$, nitrite- $\mathrm{N}$, ammonia-N and $\mathrm{pH}$. TN adopted the ultraviolet spectrophotometric method of potassium perchlorate oxidation. Nitrate-N and nitrite-N took ion chromatography methods. Nessler's reagent spetcrophotometry method was used to test ammonia-N. Chloride ion was prepared by sodium chloride, and $\mathrm{KNO}_{3}$ and $\mathrm{NH}_{4} \mathrm{Cl}$ were used for corresponding solution. All the chemicals were analytically pure and the experimental water was pure water. $\mathrm{pH}$ meter was Hach $\mathrm{pH}$ meter (HQ11d).

\subsection{Sampling location}

Raw tail water sampled from WWTP in Caofeidian new city of Tangshan Hebei China, and it is away $3 \mathrm{~km}$ from Bohai bay. The water samples were taken in May dry season. In the dry season, it is less rainfall, and the groundwater leaks less into underground pipes. The chloride ion concentration in in tail water was relatively low. The chloride ion concentration in the sampled water this time was $1127 \mathrm{mg} / \mathrm{L}$. In contrast, groundwater level in rainy season is high, more groundwater leaks into pipes, and the chloride ion in secondary effluent was about 2000 $\sim 3000 \mathrm{mg} / \mathrm{L}$ or even plus in daily monitoring. Due to the limitation of sampling time and space, the recording high value was about $10000 \mathrm{mg} / \mathrm{L}$. The sampled water quality parameters were as table 1 .

Table 1 Water quality of wastewater treatment plant

\begin{tabular}{ccccccc}
\hline \multirow{2}{*}{$\begin{array}{c}\mathrm{COD}_{\mathrm{Cr}} \\
\text { parameters }\end{array}$} & $\mathrm{pH}$ & chloride ion & ammonia-N & nitrite-N & nitrate-N \\
& & & $(\mathrm{mg} / \mathrm{L})$ & $(\mathrm{mg} / \mathrm{L})$ & $(\mathrm{mg} / \mathrm{L})$ & $(\mathrm{mg} / \mathrm{L})$ \\
\hline value & 66 & 7.3 & 1171 & 1.18 & 0.39 & 8.08 \\
\hline
\end{tabular}




\subsection{Experimental procedures}

\subsubsection{Linear volt-ampere curve}

This experiment conducted in the solution with $25 \mathrm{mg} / \mathrm{L} \mathrm{NO}_{3}{ }^{-} \mathrm{N}$ and $0.1 \mathrm{~mol} / \mathrm{L} \mathrm{Na}_{2} \mathrm{SO}_{4}$. Uniformly negative linear voltage was applied between $-2.5 \mathrm{~V}$ and $0 \mathrm{~V}$ by an electrochemical workstation. The obtained curve is the linear volt-ampere curve.

\subsubsection{Chloride electrolysis}

In the experiment, cathode potential was set $-1.6 \mathrm{~V}$, and the initial $\mathrm{pH}$ value of electrolyte was 7 . In the configured water samples, the initial nitrate-N and ammnia- $\mathrm{N}$ was $20 \mathrm{mg} / \mathrm{L}$ and $10 \mathrm{mg} / \mathrm{L}$, initial chloride ion was configured as $1000 \mathrm{mg} / \mathrm{L}, 2000 \mathrm{mg} / \mathrm{L}$, and $3000 \mathrm{mg} / \mathrm{L}$ respectively in different solutions. The aim was to investigate the effect of initial chloride ion concentration on denification.

\subsubsection{Nitrogen removal test under different voltages}

In order to explore the nitrogen removal effect, a proper cathodic potential should be got. Known from the linear volt ampere curve in Fig.3, the electrolytic current increased with applied voltage starting from 0V. The inflection point appeared when the cathode potential was about $-1.1 \mathrm{~V}$ and then the current suddenly dropped. When the cathodic potential was $-1.2 \mathrm{~V}$, a strong reduction appeared and it was the reduction peak of $\mathrm{NO}_{3}^{-}$. Then, with voltage increasing from $-1.2 \mathrm{~V}$, the current increased again. According to the characteristics of the linear volt-ampere curve, the proper potential should be chosen between $-1.8 \mathrm{~V}$ and $-1.2 \mathrm{~V}$, and which would be taken as the cathodic potential of denitrification. 


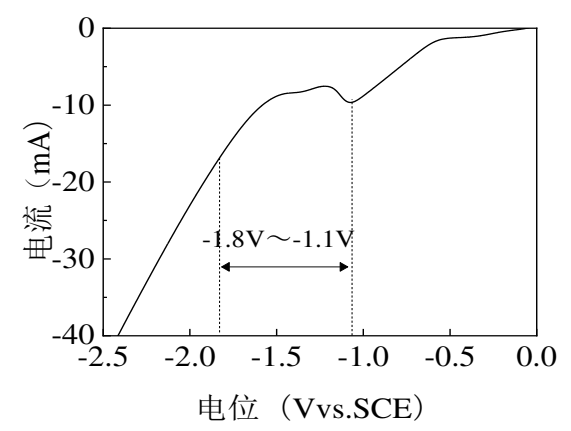

Fig. 2 Linear volt ampere curve

\section{Results and discussion}

\subsection{Comparison of electrode materials}

In the experiment, oxygen evolution was the main competitive side reaction and it affected the current efficiency. For chloride evolution, the chloride evolution over potential determined the efficiency of chloride evolution reaction, during the process, free chloride generated with strong oxidization and which oxidized ammonia-N. So the oxidation/chloride evolution should all be considered in the experiment. Oxygen/chloride evolution polarization curves of three different anode materials were measured in $0.5 \mathrm{~mol} / \mathrm{L}$ sodium sulfate and saturated sodium chloride solution, separately. According to the above analysis, the process for selecting proper electrodes were stated below.

Three electrodes were used to conduct the experiment. Known from Fig.2, Ti/ $\mathrm{RuO}_{2}-\mathrm{SnO}_{2}$ has the smallest difference value between oxygen/chloride evolution comparing with that of other two materials. And the value was $0.45 \mathrm{~V}$. The oxygen evolution was the lowest. In the electrochemical reaction, competitive adsorption of $\mathrm{OH}^{-}$and $\mathrm{Cl}^{-}$ happened on electrode surface. The smaller of the potential difference, the more the oxygen evolution side reaction occurred and the more current was used for oxygen evolution. This reduced the current efficiency for ammonia- $\mathrm{N}$ 
removal. The oxygen/chloride evolution of $\mathrm{Ti} / \mathrm{RuO}_{2}-\mathrm{IrO}_{2}$ ( $\mathrm{Zhi}$ et al., 2020; ) ranked the second with value $0.50 \mathrm{~V}$, but the chloride evolution was the highest $0.98 \mathrm{~V}$. For instance, if the chloride evolution was too high, it would increase the voltage of reaction tank and energy consumption would increase accordingly. The voltage difference of $\mathrm{Ti} / \mathrm{IrO} \mathrm{r}_{2}$ was the biggest $0.56 \mathrm{~V}$ with the lowest chloride evolution. The oxygen evolution was among two other electrodes. When the voltage difference of oxygen/chloride evolution was large and it would reduce the generation of side reaction. The lower the chloride evolution was, the easier the free chloride being produced. Thus, the ammonia-N removal efficiency improved. So taking $\mathrm{Ti} / \mathrm{IrO}_{2}$ as anode material was more suitable than the other two ways in this research. $\mathrm{Ti} / \mathrm{IrO}_{2}$ became the most appropriate anode with these advantages, such as highly conducting, physically hard and chemically stable and inert.

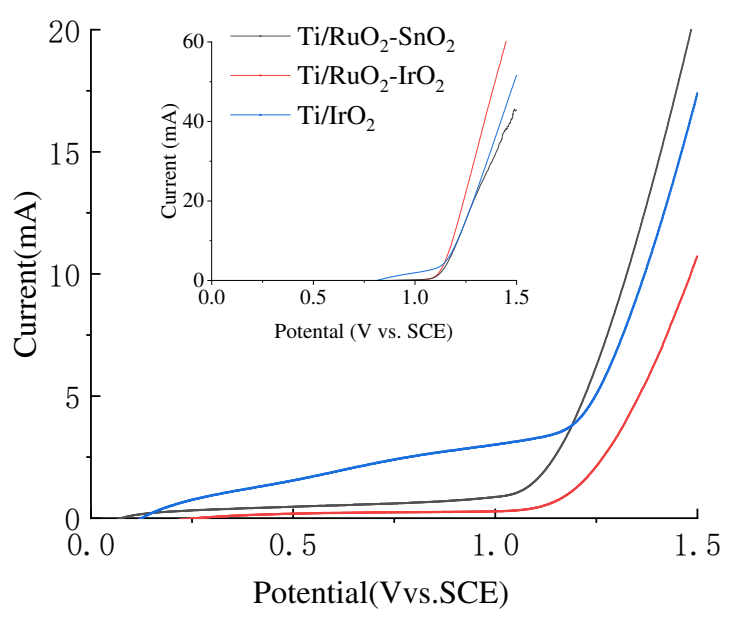

Fig. 3 Oxygen/chlorine evolution polarization curves of three electrodes (the imbedded figure is the chlorine evolution curve, the large figure is the oxygen evolution curve) 


\subsection{Nitrogen removal under different chloride ion concentration}

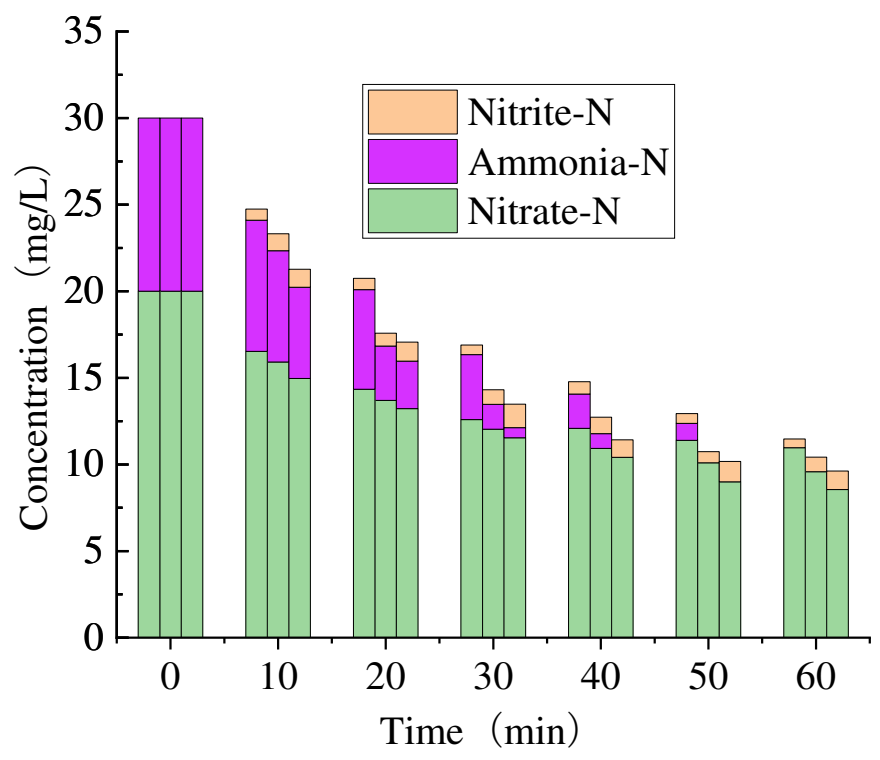

Fig. 4 Effect of different chloride ion concentration on nitrogen removal

(The initial nitrate- $\mathrm{N}$ and ammonia- $\mathrm{N}$ concentration in Fig. 4 were 10 , and $20 \mathrm{mg} / \mathrm{L}$, respectively. In each three-data-group in the seven time points, ammonia-N, nitrite-N and nitrate-N were tested with the chloride ion $1000,2000,3000 \mathrm{mg} / \mathrm{L}$ from left to right.)

Seen from Fig. 4, nitrate-N and ammonia-N concentration decreased gradually with the prolonging of electrolysis time. Nitrite-N came to appear within 10 min. Ammonia-N was not detected for the first time at the chloride ion concentration $3000 \mathrm{mg} / \mathrm{L}$ and the time $40 \mathrm{~min}$. Electrolysis time $50 \mathrm{~min}$ and chloride ion concentration $2000 \mathrm{mg} / \mathrm{L}$, ammonia-N was all removed. All the ammonia-N was removed when the time lasted $60 \mathrm{~min}$. The removal effect of ammonia-N was mainly caused by free chloride. With the promoting of chloride ion in solution, the producing amount of free chloride would increase accordingly, so the oxidation efficiency of free chloride on ammonia-N became higher. The reaction was just depicted as formula (1) (2).

For nitrite-N, its concentration was about $1 \mathrm{mg} / \mathrm{L}$ when the time $10 \mathrm{~min}$, and there was no obvious change after that time. In this case, the concentration of nitrate- $\mathrm{N}$ had a little effect on the nitrite- $\mathrm{N}$ concentration. The effect 
occurred during the transformation of nitrogen gas from nitrate-N, part of which turned into nitrite-N ((Choi et al., 2016)). Nitrite- $\mathrm{N}$ as the intermediate product was a non-negligible product produced during the transformation from nitrate-N to nitrogen gas. This agreed on previous peers (Rao et al., 2019; Dash et al., 2005). During the electrolysis, ammonia-N also might transform to nitrite- $\mathrm{N}$ or further into nitrate- $\mathrm{N}$, just as formula (3), but there is no effect on the existence of nitrite-N. Based on this, when the ammonia-N was all oxidized, the nitrite-N still kept the constant value (Ma et al., 2020). But the whole process should be verified in more experiments.

The increase in chloride ion concentration and prolonged electrolysis time, allowed the removal efficiency of ammonia-N and nitrate-N to go up. The total concentration of the three nitrogen-containing substances decreased. The transformation process was shown in formula (4) (7), nitrate-N was reduced to nitrite-N and nitrogen gas, and nitrite-N was also reduced to nitrogen gas or ammonia-N (Kuang et al., 2020; Zhang et al., 2021). When the chloride ion concentration was 2000 and $3000 \mathrm{mg} / \mathrm{L}$, the concentration difference with different electrolysis time was small. But with the chloride ion concentration $1000 \mathrm{mg} / \mathrm{L}$, the sum of three nitrogen-containing substances concentration was obviously higher than the other two. However, it was opposite with the time 60min. Within $60 \mathrm{~min}$, the total concentration of three nitrogen-containing solutions was all lower than $15 \mathrm{mg} / \mathrm{L}$. That could be explained by that appropriate chloride ion dosage was beneficial for the removal of nitrite-N. Furthermore, different nitrate concentration corresponded to different proper chloride ion dosage. According to the analysis and Fig. 4, there is no obvious difference in the nitrogen-containing removal under different chloride ion concentration. Therefore, the chloride ion concentration was configured $2000 \mathrm{mg} / \mathrm{L}$ in the following experiment.

The proposed reaction formula shown as followed (Kim et al., 2005; Ji et al., 2021; Moura et al., 2005):

$$
\begin{aligned}
& \mathrm{Cl}^{-} \rightarrow \mathrm{Cl}_{2} \rightarrow \mathrm{HOCl} \rightarrow \mathrm{OCl}^{-} \\
& \mathrm{NH}_{3}+\mathrm{OCl}^{-} \rightarrow \mathrm{N}_{2}+\mathrm{HCl}
\end{aligned}
$$




$$
\begin{gathered}
\mathrm{NH}_{3} \rightarrow \mathrm{NH}_{2} \mathrm{OH}_{\mathrm{ad}} \rightarrow \mathrm{NOH}_{\mathrm{ad}} \rightarrow \mathrm{NO} \rightarrow \mathrm{NO}_{2}^{-} \rightarrow \mathrm{NO}_{3}^{-} \\
\mathrm{NO}_{2}^{-}+\mathrm{H}_{2} \mathrm{O} \rightarrow \mathrm{NH}_{3}+\mathrm{OH}^{-} \\
\mathrm{NO}_{2}^{-}+\mathrm{H}_{2} \mathrm{O} \rightarrow \mathrm{N}_{2}+\mathrm{OH}^{-} \\
\mathrm{NO}_{3}^{-}+\mathrm{H}_{2} \mathrm{O} \rightarrow \mathrm{NH}_{3}+\mathrm{OH}^{-} \\
\mathrm{NO}_{3}^{-}+\mathrm{H}_{2} \mathrm{O} \rightarrow \mathrm{NO}_{2}^{-}+\mathrm{OH}^{-}
\end{gathered}
$$

\subsection{Effect of cathode potential on nitrogen removal}

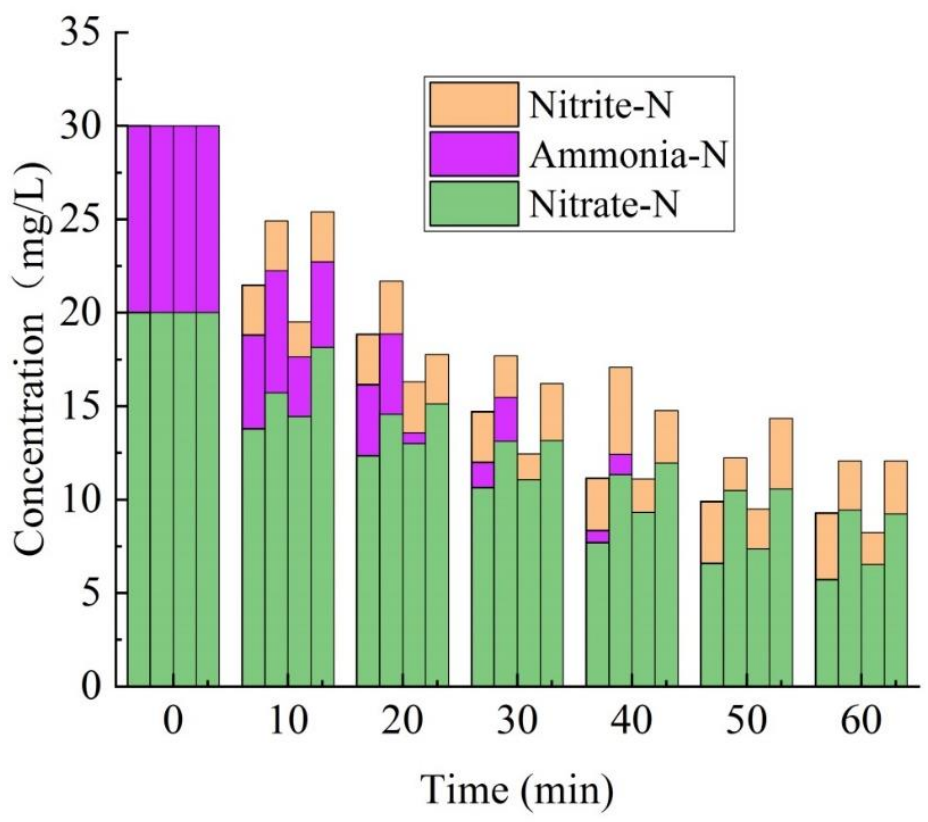

Fig. 5 Effect of cathode potential on nitrogen removal

(In Fig. 5, the initial ammonia-N and nitrate-N concentration was 10 , and $20 \mathrm{mg} / \mathrm{L}$ respectively. In seven time points, the test was conducted. Four sets of data formed a time point group, and in each group, ammonia-N, nitrate- $\mathrm{N}$ and nitrite- $\mathrm{N}$ were measured under the cathodic potential $-1.2,-1.4,-1.6,-1.8 \mathrm{~V}$ from left to right.)

Known from Fig. 5, nitrite-N and ammonia-N concentration decreased gradually with time prolonged. 
Nitrate-N turned up for the first time in the four water samples within the time $10 \mathrm{~min}$. In the following process, there was no obvious concentration difference under different cathodic potential.

With the increase of cathodic potential, removal efficiency of ammonia- $\mathrm{N}$ increased gradually and the best removal efficiency appeared at $-1.8 \mathrm{~V}$. When it was $10 \mathrm{~min}$, ammonia-N could not be detected. The followed potential order was $-1.6 \mathrm{~V}$ and $-1.8 \mathrm{~V}$. But for the potential $-1.2 \mathrm{~V}$ and $-1.4 \mathrm{~V}$, the removal efficiency was lower and removed completely within $50 \mathrm{~min}$. The main reason was that the increasing cathodic potential allowed cell voltage to increased, which led to increased current density on unit area, more electrons transferred, more free chlorine. Then the free chlorine reacted with ammonia-N, which showed faster removal efficiency. The result was similar to Guo Di’s research (Guo et al., 2016).

In terms of nitrate-N removal, the removal efficiency was the best when the cathodic potential was $-1.2 \mathrm{~V}$ and it was $71.42 \%$ within $60 \mathrm{~min}$. This was consistent with the linear volt-ampere curve above. The reduction peak occurred at $-1.2 \mathrm{~V}$. Next, when the cathodic potential was $-1.6 \mathrm{~V}$, the removal efficiency was $67.4 \%$; but for $-1.8 \mathrm{~V}$, the efficiency was the lowest. This could be explained as the fact that the negative potential shift intensified the occurrence of hydrogen evolution reaction. And the increased hydrogen evolution reaction produced more bubbles, which not only reduced the adsorption area, but also led to the competitive adsorption of $\mathrm{H}+$ and $\mathrm{NO}_{3}{ }^{-}$. This, therefore, reduced the current efficiency and affected the removal efficiency.

The formation of nitrite- $\mathrm{N}$ as depicted in Fig. 5, under different cathodic potential, nitrate-N concentration increased faster within the first $10 \mathrm{~min}$, and reached $2 \sim 4 \mathrm{mg} / \mathrm{L}$, but It fluctuated up and down in a certain range after $10 \mathrm{~min}$. when the cathodic potential was $-1.6 \mathrm{~V}$, it produced relatively little nitrite-N. which as the intermediate produce produced during the reduction process from nitrate- $\mathrm{N}$ to nitrogen gas, the cathodic potential was less selective to its formation. It also showed that, nitrite-N was a noteworthy factor affecting the removing of nitrate-N. 
An interesting phenomenon could be seen from the above analysis and Fig. 5. During the electrolysis process, when the cathodic potential was $-1.6 \mathrm{~V}$, the three nitrogen-N substances - ammonia- $\mathrm{N}$, nitrate- $\mathrm{N}$ and nitrite- $\mathrm{N}$ all achieved the highest removal efficiency $82.3 \%$. The value was better than that in the reduction peak potential $-1.2 \mathrm{~V}$, and the selectivity of nitrogen generation was higher at this time. At the same time, it was very important to choose appropriate cathode potential for electrochemical denitrification. If the cathode potential was too low, the current density was relatively low, the catalytic effect was not satisfactory, and the removal efficiency also decreased. If the cathode potential was too high, the hydrogen evolution reaction would be violent, affecting the nitrate-N removal efficiency. So, in the following experiment, $-1.6 \mathrm{~V}$ was chosen as the cathodic potential.

\subsection{Nitrogen removal under different $\mathrm{pH}$ conditions}
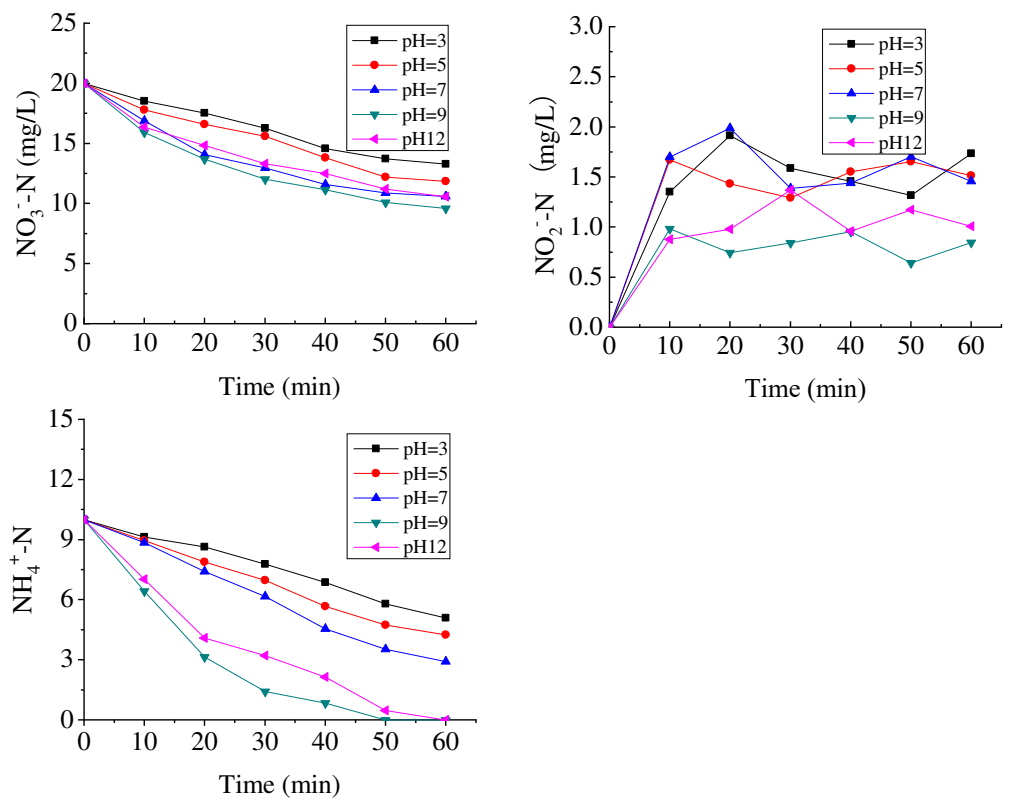

Fig. 6 Nitrogen removal and variation of $\mathrm{pH}$ in solution under different $\mathrm{pH}$ conditions

Seen from Fig. 6, initial $\mathrm{pH}$ value in solution had great affect the on the removal efficiency of ammonia-N.

When the $\mathrm{pH}$ was 3, the removal efficiency of ammonia-N was the lowest with the time $60 \mathrm{~min}$ and the value was 48.8\%. The removal efficiency increased with the increase in initial $\mathrm{pH}$ value. When the initial $\mathrm{pH}$ equaled 9 and 
the time was $50 \mathrm{~min}$, ammonia-N could not be detected in the solution. Then, with the increasing $\mathrm{pH}$ value, the removal efficiency slowed down. When $\mathrm{pH}$ was 12 and the time was $60 \mathrm{~min}$, ammonia-N was removed completely, and the efficiency was better than that when the $\mathrm{pH}$ value was 3,5 , and 7 , respectively. The phenomenon was that, the removal efficiency of ammonia-N gradually increased and then slowed down with the $\mathrm{pH}$ value increasing. This suggested that the removal efficiency of ammonia-N under weak alkali condition was higher than that under strong alkali and acid conditions (Yao et al., 2016). Under the acidic conditions, ammonia-N mainly exists in the form of $\mathrm{NH}_{4}{ }^{+}$, which is not easy to be oxidized compared with $\mathrm{NH}_{3}$. Moreover, $\mathrm{Cl}_{2}$ overflows easily and free chloride concentration reduces. Under the condition of strong alkali, there is a large amount of $\mathrm{OH}^{-}$in solution, which will diffuse to the anode during electrolysis process and adsorb competitively with $\mathrm{Cl}^{-}$. In addition, $\mathrm{OH}^{-}$reacts with free chloride forming $\mathrm{ClO}_{3}^{-}$, which hinders the oxidation of ammonia-N. This is consistent with the conclusion of Qin Jingjing ((Qin, 2016)).

When initial $\mathrm{pH}$ was 3, the removal efficiency of nitrite-N was the lowest, only $33.6 \%$. When the initial $\mathrm{pH}$ was 9 , the best removal efficiency reached $52.1 \%$. However, with $\mathrm{pH} 12$, the efficiency dropped. This was, to some extent, different from Ding Jing and Zhang Dongmei's research. Dingjing thought the effect of $\mathrm{pH}$ on the removal of nitrate-N was not obvious (Ding, 2016). Differently, Zhang Mei believed it was beneficial to nitrate-N reduction when the initial pH was low (Zhang, 2013). Their different opinions consisted in the decreasing $\mathrm{H}^{+}$concentration gradually with the increasing $\mathrm{pH}$. According to formula(1), there is a dynamic equilibrium between $\mathrm{OCl}^{-}$and $\mathrm{H}^{+}$: the $\mathrm{OCl}^{-}$concentration went down, weakening the oxidation of $\mathrm{OCl}^{-}$on ammonia-N and other nitrogen-containing substances. The removal efficiency of nitrate-N went up. When the $\mathrm{pH}$ was higher, the competent absorption between $\mathrm{OH}^{-}$or other substances and $\mathrm{H}^{+}$occurred on the electrode, which hindered the removal of nitrate-N. The removal efficiency of nitrate-N increased with the increasing $\mathrm{pH}$. 
To some extent, the production of nitrite- $\mathrm{N}$ was affected by $\mathrm{pH}$ value, but the effect was slight. In the first $10 \mathrm{~min}$, the nitrite-N concentration went up quickly, and then fluctuated within a certain range, and the concentration value kept between 0.8 and $1.6 \mathrm{mg} / \mathrm{L}$. The lower $\mathrm{pH}$, the less the produced nitrite-N. When the initial $\mathrm{pH}$ was 9 , the amount of nitrite-N was the least. Under weak alkali condition it was lower than that under strong alkali and acid condition. The effect of nitrite-N removal rule was familiar to that of ammonia-N. Further research is expected in the effect of $\mathrm{pH}$ on nitrite-N removal.

\subsection{Nitrogen removal efficiency in raw and optimized raw water}

Fig. 7 depicted the denitrification effect of electrolyzed wastewater samples under different conditions. After 60 mins' electrolysis, it could be seen that the concentration of nitrogen-containing substances showed a downward trend, and the removal efficiency of the optimized wastewater was significantly higher than that of the wastewater without optimization. Under the optimal conditions, the reduction rate of nitrate-N was more quickly, and the removal efficiency was $56.93 \%$ and $71.41 \%$ respectively before and after optimization. Under the condition of optimal raw water parameters, the org-N removal efficiency was much higher than that of raw water. The nitrite-N concentration increased and stayed at a certain level. In contrast, the concentration of the optimal raw water maintained and showed no obvious change under the optimized operating parameters. This might attribute to the faster oxidization of nitrite-N caused by increasing $\mathrm{Cl}^{-}$concentration. Ammonia-N was not detected during the electrolysis, because its concentration was rather low, $1.18 \mathrm{mg} / \mathrm{L}$ and it had been completely oxidized in a short time. This fact was contrary to the research whose conclusion was that ammonia-N increased first and then decreased while nitrite-N was not detected (Shen, 2020). The TN decreased quickly under the optimal parameters with its concentration $3.87 \mathrm{mg} / \mathrm{L}$ in $60 \mathrm{~min}$ and the removal efficiency being $71.2 \%$. In summary, the optimal operational parameters were better than that or raw water and better electrolysis denitrification. It was consistent with the 
prepared wastewater results. That is to say, the chloride ion concentration in rainy season is much higher than other seasons, the electrochemical denitrification efficiency is better, and the tests is supposed to be carried out in the future experiments.

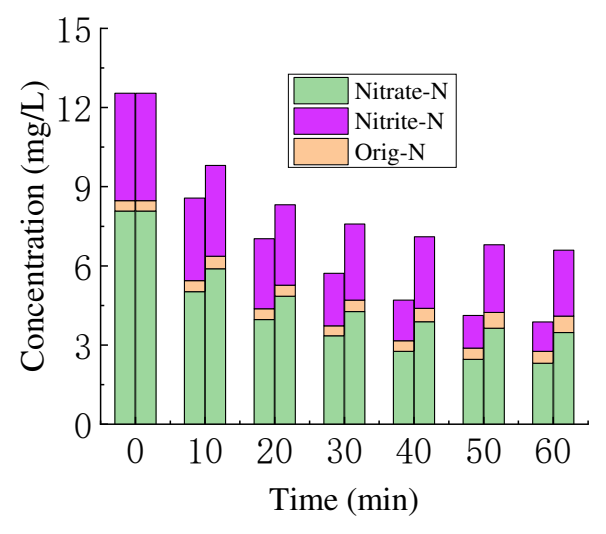

Fig. 7 Concentration changes of org-N, nitrite-N, nitrate $-\mathrm{N}$ and $\mathrm{TN}$ under different conditions (in each group, it was the optimal and raw water sample from left to right)

\section{Conclusions}

The research conducted the electrochemical denitrification in the tailwater, simulated and optimal tailwater. Tailwater sampled from WWTP of costal industrial park and it had the characteristics of high chloride and low carbon resource. The following conclusions were drawn.

The concentration of initial chloride ion concentration 2000 and $3000 \mathrm{mg} / \mathrm{L}$ made no obvious difference to the nitrogen removal. Ammonia-N was completely removed in $60 \mathrm{~min}$, and the nitrite-N concentration was about $1 \mathrm{mg} / \mathrm{L}$. In the course of experiment, with the increasing cathodic potential, the removal efficiency of ammonia-N went up gradually, ammonia-N in different water samples were completely removed completely in 50 min. by comparison, the conclusion on nitrate nitrogen was opposite. When the cathodic potential was $-1.2 \mathrm{~V}$, the highest efficiency was $71.4 \%$ and the nitrite- $\mathrm{N}$ amount was the least at $-1.6 \mathrm{~V}$. For $-1.6 \mathrm{~V}$, pH had great influence on the 
removal of ammonia-N: with the increase in $\mathrm{pH}$, the removal of ammonia- $\mathrm{N}$ and nitrate- $\mathrm{N}$ increased firstly and then decreased. The best result appeared at $\mathrm{pH}$ being 9 , nitrite- $\mathrm{N}$ was less affected by $\mathrm{pH}$ value. By comparing the raw and optimized raw water samples, the reduction efficiency of nitrate- $\mathrm{N}$ in optimized raw water increased from $56.9 \%$ to $71.4 \%$, nitrite-N concentration kept constant, and TN removal efficiency also increased significantly.

\section{Ethics approval}

Not applicable

\section{Consent to Participate}

Informed consent was obtained from all individual participants included in the study.

\section{Consent to Publish}

Not applicable.

\section{Credit authorship contribution statement}

Yaozong Zhang: Conceptualization, Methodology, Software, Investigation, Writing -original draft. Bo Pang:

Validation, Formal analysis, Visualization, Software, Writing - review \& editing.

\section{Declaration of competing interest}

The authors declare that they have no competing interests

\section{Acknowledgements}

The authors gratefully acknowledge the funding from Doctoral Research Startup Fund of the North China University of science and technology (28409899), Tangshan science and technology innovation team training plan $(19130208 \mathrm{C})$

\section{Data Availability Statement}

The datasets used and/or analysed during the current study are available from the corresponding author on 
reasonable request.

\section{References}

Beltramea TF, Gomes MC, Marder L, Marchesini FA, Ulla M, Andrea MB (2020) Use of copper plate electrode and Pd catalyst to the nitrate reduction in an electrochemical dual-chamber cell. Journal of Water Process Engineering 35(101189): 1-8. https://doi.org/10.1016/j.jwpe.2020.101189

Choi HM, Lee S, Moon S, Phan TN, Jeon SG, Ko CH (2016) Comparison between unsupported mesoporous $\mathrm{Co}_{3} \mathrm{O}_{4}$ and supported $\mathrm{Co}_{3} \mathrm{O}_{4}$ on mesoporous silica as catalysts for $\mathrm{N}_{2} \mathrm{O}$ decomposition. Catal Commun 82: 50-54. https://doi.org/10.1016/j.catcom.2016.04.022

Chun D, Lim CR, Lee HS, Yoon WS, Lee TK, Kim DK, (2018) Electrochemical treatment of urine by using $\mathrm{Ti} / \mathrm{IrO}_{2} / \mathrm{TiO}_{2}$ electrode. Journal of Water Process Engineering 26:1-9.

https://doi.org/10.1016/j.jwpe.2018.06.004

Dash BP, Chaudhari S (2005) Electrochemical denitrificaton of simulated ground water. Water Res 39:4065-4072. https://doi.org/10.1016/j.watres.2005.07.032

Kim DE, Pak D (2019) Ti plate with $\mathrm{TiO}_{2}$ nanotube arrays as a novel cathode for nitrate reduction. Chemosphere 228:611-618. https://doi.org/10.1016/j.chemosphere.2019.04.071

Ding J (2015) Pperformance and mechanism of simultaneous nitrogen-removal and disinfection for advanced wastewater treatment by electrochemical process. Harbin institute of technology.

Guo D (2016) Study on treatment of ammonia nitrogen in mariculture wastewater by electrochemical technology. Zhejiang University.

Garcia-Segura S, Mostafa E, Baltruschat H (2019) Electrogeneration of inorganic chloramines on boron-doped diamond anodes during electrochemical oxidation of ammonium chloride urea and synthetic urine matrix.

Water Research 160:107-117. https://doi.org/10.1016/j.watres.2019.05.046

Jiang X, Ying DW, Liu X, Liu MC, Zhou S, Guo CY, Zhao GH, Wang YL, Jia JP (2020) Identification of the role of $\mathrm{Cu}$ site in $\mathrm{Ni}-\mathrm{Cu}$ hydroxide for robust and high selective electrochemical ammonia oxidation to nitrite.

Electrochimica Acta 345(136157): 1-13. https://doi.org/10.1016/j.electacta.2020.136157. 
Ji YY, Niu JF, Xu D, Wang KX, Brejcha J, Jeon S, Warsinger DM (2021) Efficient electrocatalysis for denitrification by using $\mathrm{TiO}_{2}$ nanotube arrays cathode and adding chloride ions. Chemosphere 274(129706):1-8. https://doi.org/10.1016/j.chemosphere

Kamai R, Nakanishi S, Hashimoto K, Kamiya K (2017) Selective electrochemical reduction of nitrogen oxides by covalent triazine frameworks modified with single Pt atoms. Journal of electroanalytical chemistry 800: 54-59. http://dx.doi.org/10.1016/j.jelechem.2016.09.027

Liu F, Liu K, Li M, Hu SH, Li J, Lei XH, Liu X (2019) Fabrication and characterization of a Ni-TNTA bimetallic nanoelectrode to electrochemically remove nitrate from groundwater. Chemosphere 223:560-568. https://doi.org/10.1016/j.chemosphere.2019.02.028 .

Ma XJ, Li M, Feng CP, Hu WW, Wang LL, Liu X (216) Development and reaction mechanism of efficient nanotitanium electrode: reconstructed nanostructure and enhanced nitrate removal efficiency. Journal of Electroanalytical Chemistry 782: 270-277. http://dx.doi.org/10.1016/j.jelechem.2016.10.047

Ma XJ, Li M, Feng CP, He Z (2020) Electrochemical nitrate removal with simultaneous magnesium recovery from a mimicked RO brine assisted by in situ chloride ions. Journal of Hazardous Materials 388(122085):1-10 https://doi.org/10.1016/j.jhazmat.2020.122085

Kim K1, Kim Y, Kim I, Park G, Lee E (2005) The electrolytic decomposition mechanism of ammonia to nitrogen at an $\mathrm{IrO}_{2}$ anode. Electrochimica Acta 50: 4356-4364

Kuang PJ, Natsui K, Feng CP, Einaga Y (2020) Electrochemical reduction of nitrate on boron-doped diamond electrodes: Effects of surface termination and boron-doping level. Chemosphere 251(126364): 1-11. https://doi.org/10.1016/j.chemosphere.2020.126364

Moura DCD, Brito CDN, Quiroz MZ, Pergher SBB, Martinez-Huitle CA (2015) Cl-mediated electrochemical oxidation for treating an effluent using pla-tinum and diamond anodes. $J$ Water Process Eng 8: e31-e36. https://doi.org/10.1016/j.jwpe.2014.11.005

Qin JJ (2016) Research on removal of nitrogenous contaminants in wastewater by electrochemical catalytic oxidation. Shanxi University of science and technology.

Rao XF, Shao XL, Xu J, Yi J, Qiao JL, Li QY, Wang HQ, Chien MF, Inoue C, Liu YY, Zhang JJ (2019) Efficient nitrate removal from water using selected cathodes and $\mathrm{Ti} / \mathrm{PbO}_{2}$ anode: Experimental study and mechanism 
verification. Separation and Purification Technology 216: 158-165.

https://doi.org/10.1016/j.seppur.2019.02.009

R BA, Lahav O (2016) Electrooxidation for simultaneous ammonia control and disinfection in seawater recirculating aquaculture systems. J Aquac Eng Fish Res 72: 77-87.

https://doi.org/10.1016/j.aquaeng.2016.05.002

Santos ID, Santos KB, Oliveira LMSS, Radino-Rouse P Dutra, AJB (2019) Influence of some parameters on the nitrate formation during ammonia electrooxidation from an effluent generated by fertilizers' storage and handling facilities. Journal of Environmental Chemical Engineering 7 (103123): 1-8. https://doi.org/10.1016/j.jece.2019.103123

Shen ZH, Liu DR, Peng GG, Ma YH, Li JS, Shi JL, Peng JB, Ding LL (2020) Electrocatalytic reduction of nitrate in water using $\mathrm{Cu} / \mathrm{Pd}$ modified $\mathrm{Ni}$ foam cathode: High nitrate removal efficiency and $\mathrm{N}_{2}$-selectivity Separation and Purification Technology 241(116743): 1-11. https://doi.org/10.1016/j.seppur.2020.116743

Teng W, Bai N, Liu Y,Fan JW Zhang, WX (2018) Selective Nitrate Reduction to dinitrogen by electrocatalysis on nanoscale Iron encapsulated in mesoporous carbon. Environ Sci Technol 52: 230-236. https://doi.org/10.1021/acs.est.7b04775

Wang H, Zhang X, Su Y, Yu HT, Chen S, Quan X, Yang FL (2014) Photoelectrocatalytic oxidation of aqueous ammonia using $\mathrm{TiO}_{2}$ nanotube arrays. Appl Surf Sci 311: 851-857.

Yao Fb, YangQ, ZhongY, Shu XY, Chen F, Sun J, Ma YH, Fu ZY, Wang DB, Li WM (2019) Indirect electrochemical reduction of nitrate in water using zero-valent titanium anode: Factors kinetics and mechanism. Water Research 157: 191-200. https://doi.org/10.1016/j.watres.2019.03.078

Yao JC, Zhou MM,Wen DN, Wang JD (2016) Electrochemical conversion of ammonia to nitrogen in non-chlorinated aqueous solution by controlling pH value. Journal of Electroanalytical Chemistry 776: 53-58. http://dx.doi.org/10.1016/j.jelechem.2016.06.040

Yao JY, Mei Y YuanTB, Chen J, Pan H, Wang JD (2021) Electrochemical removal of nitrate from wastewater with a Ti cathode and Pt anode for high efficiency and $\mathrm{N}_{2}$ selectivity. Journal of Electroanalytical Chemistry 882 (115019): 1-7. https://doi. org/10.1016/j.jelechem.2021.115019.

Zöllig H, Remmele A, Morgenroth E, Udert KM (2017) Removal rates and energy demand of the electrochemical 
oxidation of ammonia and organic substances in real stored urine. Environ Sci Water Res Technol 3: 480-491. https://doi.org/10.1039/c7ew00014f.

Zhang DM (2013) Electrochemical catalytic reduction for nitrate removal from water. Qingdao University of science \& technology.

Zhang Y, Li JH, Bai J, Li XY, Shen ZX, Xia LG, ChenS, XuQJ, Zhou BX (2018) Total organic carbon and total nitrogen removal and simultaneous electricity generation for nitrogen-containing wastewater based on the catalytic reactions of hydroxyl and chlorine radicals. Applied Catalysis B: Environmental 238: 168-176. https://doi.org/10.1016/j.jclepro.2021.126639

Zhang YZ, PangB, Bo GZ, Zhang XY, Zhang W (2021) Deep Denitrification of the Simulated Coastal Secondary Effluent with High Chloride Ion by Electrolysis. Pol J Environ Stud 30(3): 1-7. https://doi.org/10.15244/pjoes/127302

Zhi D, Zhang J Wang JB, Luo L Zhou YZ, Zhou YY (2020) Electrochemical treatments of coking wastewater and coal gasification wastewater with $\mathrm{Ti} / \mathrm{Ti}_{4} \mathrm{O}_{7}$ and $\mathrm{Ti} / \mathrm{RuO}_{2}-\mathrm{IrO}_{2}$ anodes. Journal of Environmental Management 265(110571): 1-3. https://doi.org/10.1016/j.jenvman.2020.110571

Zhou B, Yu Z, Wei Q, Long HY, Xie Y, Wang Y (2016) Electrochemical oxidation of biological pretreated and membrane separated landfill leachate concentrates on boron-doped diamond anode. Appl Surf Sci 377: 406415. http://dx.doi.org/10.1016/j.apsusc.2016.03.045 
Figures

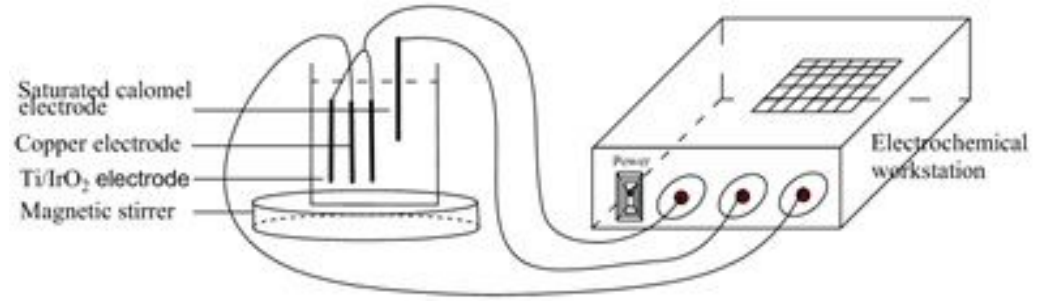

\section{Figure 1}

Experimental apparatus diagram

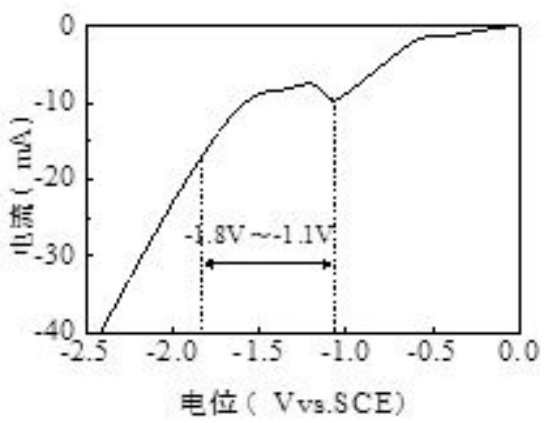

Figure 2

Linear volt ampere curve

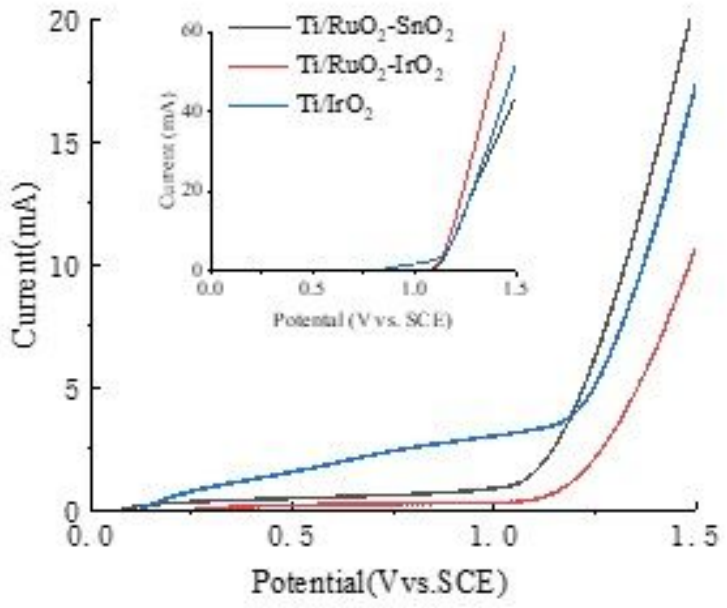

Figure 3

Oxygen/chlorine evolution polarization curves of three electrodes (the imbedded figure is the chlorine evolution curve, the large figure is the oxygen evolution curve) 


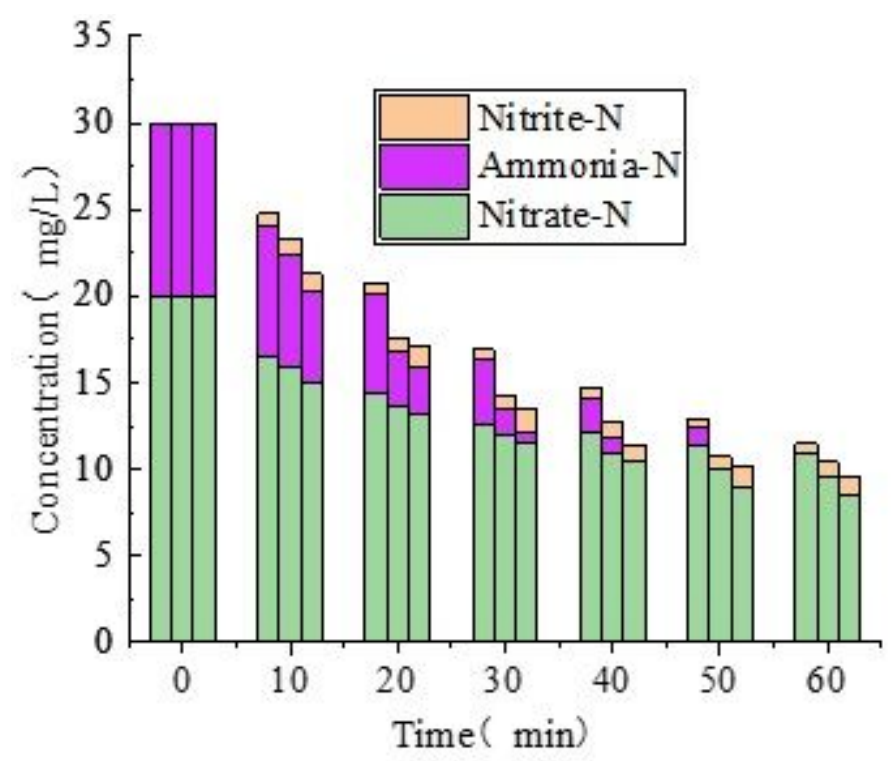

Figure 4

Effect of different chloride ion concentration on nitrogen removal

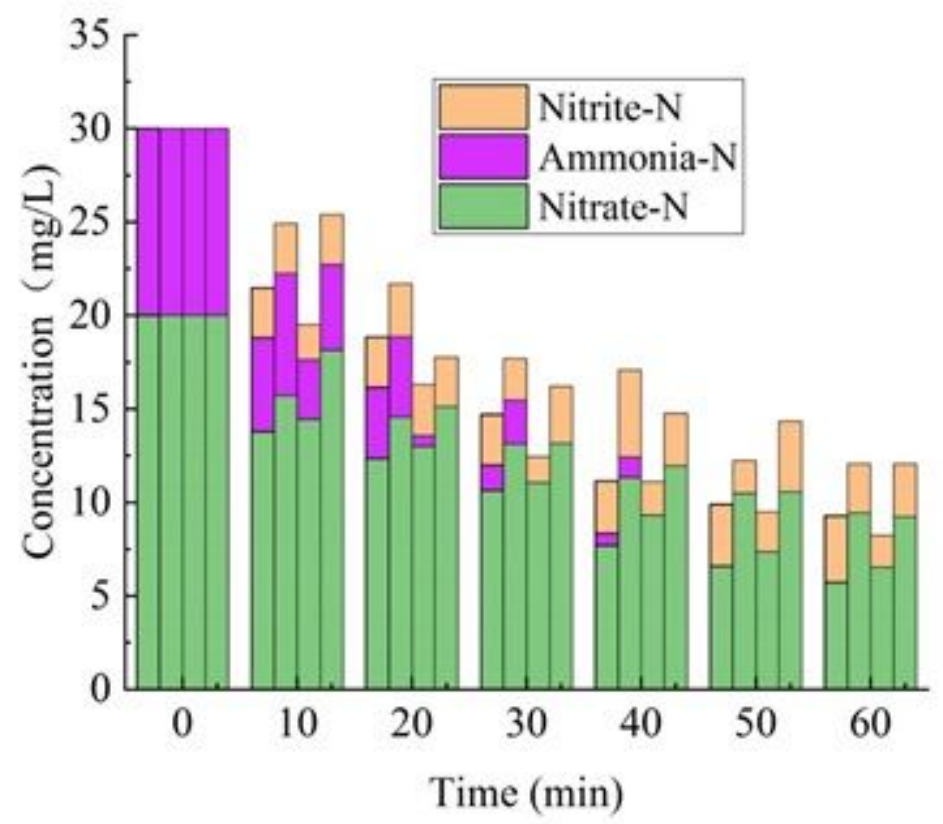

Figure 5

Effect of cathode potential on nitrogen removal 

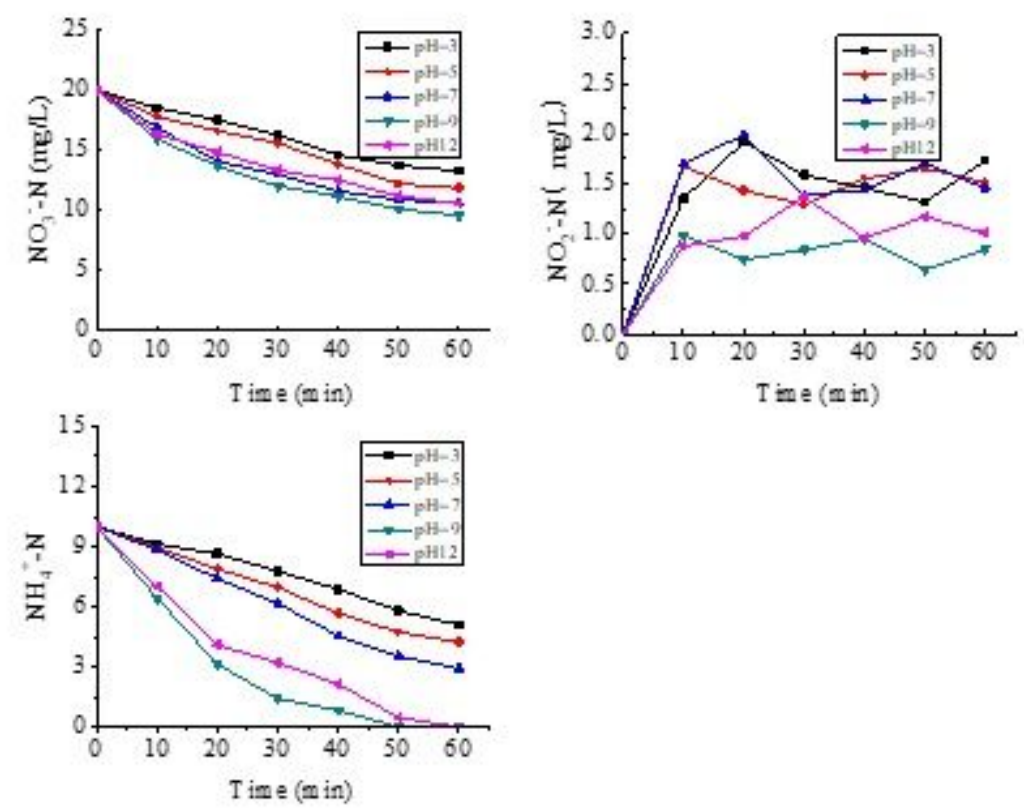

\section{Figure 6}

Nitrogen removal and variation of $\mathrm{pH}$ in solution under different $\mathrm{pH}$ conditions

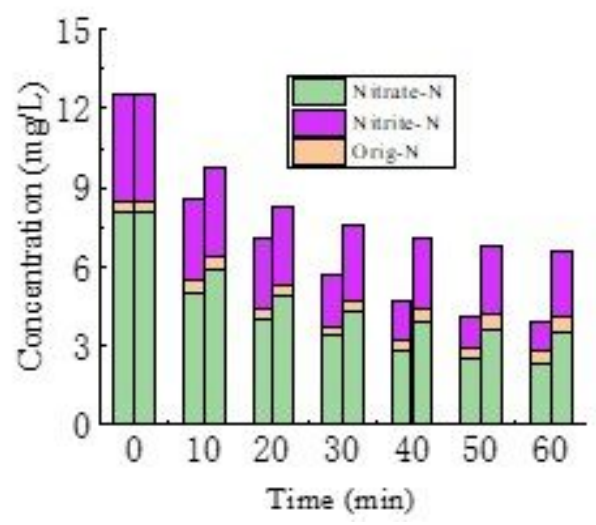

Figure 7

Concentration changes of org- $\mathrm{N}$, nitrite- $\mathrm{N}$, nitrate $-\mathrm{N}$ and TN under different conditions $囚$ in each group, it was the optimal and raw water sample from left to right $\mathbb{Z}$ 